\title{
Field Conditions Associated with Cranberry Scald
}

\author{
Paul J. Croft \\ Department of Geology and Geography, University of South Alabama, Life \\ Sciences Building, Room 136, Mobile, AL 36688-0002
}

Additional index words. Vaccinium macrocarpon, solar injury, weather stress

Scalding of cranberries (Vaccinium macrocarpon Ait., Ericaceae) may cause significant crop losses, $10 \%$ or more, in 24 to 48 h (Croft, 1992). Cranberry scald has been observed in all of the principal growing regions of the United States and Canada. Scald is characterized by a spherical pattern of damage where a physiological breakdown of fruit has occurred. Sun scald or solar injury, classified by Barber and Sharpe (1971), has been examined according to the energy balance of spherical fruits by Smart and Sinclair (1976) and considered with regard to phenophase by Renquist et al. (1987, 1989).

A widespread occurrence of scald in New Jersey during 1-3 Aug. 1990 presented a unique opportunity to examine meteorological and field conditions associated with cranberry scald before and during the event. Data were collected at a cranberry bed located at the New Jersey Rutgers Univ. Blueberry and Cranberry Research Center in Chatsworth. The portion of the bed in which observations were made was not irrigated during the growing season and was lightly sanded to cover the surface early in the season (May). The bed soil was a loamy sand, and the water table depth was maintained at $\approx 51 \mathrm{~cm}$ below the surface during the growing season.

Received for publication 21 Oct. 1994. Accepted for publication 8 Feb. 1995. The Northeast Regional Climate Center, Ocean Spray Cranberries, and the American Cranberry Growers Association provided support for this study. Thanks to Dave Fittante, Rich Hartman, Paul Eck, and Mark Shulman, and the anonymous reviewers for their beneficial contributions. The cost of publishing this paper was defrayed in part by the payment of page charges. Under postal regulations, this paper therefore must be hereby marked advertisement solely to indicate this fact.
Observations of upper canopy and midcanopy temperature, soil temperature, relative humidity, soil water potential (gypsum blocks), net radiation, and precipitation were made hourly and daily. Although attempts were made to obtain fruit temperatures, the difficulties involved (such as shading, representativeness, and destructive vs. nondestructive techniques) precluded their measurement.

Time-series plots of soil water potential at a 5-cm depth indicated that during 1-3 Aug. 1990 water potentials became more negative, falling from -0.088 to $-0.83 \mathrm{MPa}$. These maximum values occurred during the afternoon rather than in the early morning, as is typical. Mean daily values for July and August of that year were -0.059 and $-0.089 \mathrm{MPa}$, respectively. These values suggest that the bog water table (50 cm during the event) was unable (or too slow) to recharge the uppermost soil layers. Therefore, plant water demand could not be met and plants were vulnerable to water and heat stress. The soil moisture deficit developed several days prior (beginning 26 July) due to the lack of significant rainfall (for the period 25 July to 3 Aug., only $0.4 \mathrm{~mm}$ of rain fell on the bed).

The weather conditions associated with the 1990 scald event included clear skies; standard shelter air temperatures of $27 \mathrm{C}$ or higher; canopy and midcanopy temperatures up to 36 and $41 \mathrm{C}$, respectively; soil temperatures at 2 $\mathrm{cm}$ up to $26 \mathrm{C}$; and dry air (relative humidities ranging from $35 \%$ to $45 \%$-or dewpoints $\leq 12 \mathrm{C}$ ) within and above the plant canopy. For comparison, bed conditions in July and August over 5 years showed the following variations: upper canopy temperatures from 3 to $39 \mathrm{C}$, midcanopy temperatures from 2 to $43 \mathrm{C}$, soil water potentials from -0.001 to -1.50
$\mathrm{MPa}$, and 5-cm soil temperatures at $5 \mathrm{~cm}$ from 14 to $32 \mathrm{C}$

Nearly all New Jersey growers indicated that they experienced scald damage, with up to $25 \%$ of their crop affected. Damage occurred to shaded and unshaded fruit that were green before scalding and 1 to $2 \mathrm{~cm}$ in diameter. Damage varied among cultivars, with 'Early Black' most affected and 'Stevens' and 'Ben Lear' least affected. Losses were estimated by growers to be much lower (generally $<5 \%$ of fruit damaged) for fruit cooled by sprinkler irrigation. This technique is used when air temperatures exceed 29C, a grower rule of thumb. At the Research Center, visual inspections on 23 Aug. confirmed that scald damage was greatest for nonirrigated beds. Samples taken before harvest (1 Oct.) indicated that $36 \%$ of nonirrigated fruit were scalded compared to only $0.5 \%$ of those irrigated.

A search for the same combination of weather and field conditions during berry growth for five growing seasons yielded no other instances in which the critical combination of weather and field conditions occurred. During these 5 years, growers reported only minor and isolated scalding. Therefore, a specific combination of weather and field conditions that lead to an unusually high demand for water, coupled with the depletion of soil moisture, appears to be associated with cranberry scald. This interpretation supports the suppositions and observational evidence provided by others, such as Barber and Sharpe (1971) and Renquist et al. (1989). This combination should be further investigated with regard to cranberry physiology, phenophase, prediction, and mitigation.

\section{Literature Cited}

Barber, H.N. and P.J.H. Sharpe. 1971. Genetics and physiology of sunscald of fruits. Agr. Meteorol. 8:175-191.

Croft, P.J. 1992. Meteorological investigation and prediction of scald. Cranberries 56(1): 6-7, 18 .

Renquist, A.R., H.G. Hughes, and M.K. Rogoyski. 1987. Solar injury of raspberry fruit. HortScience 22:396-397.

Renquist, A.R., H.G. Hughes, and M.K. Rogoyski. 1989. Combined high temperature and ultraviolet radiation injury of red raspberry fruit. HortScience 24:597-599.

Smart, R.E. and T.R. Sinclair. 1976. Solar heating of grape berries and other spherical fruits. Agr. Meteorol. 17:241-259. 